\title{
Metode Komunikasi Yang Ideal Dalam Pendidikan Keluarga Menurut Al-Quran
}

\author{
Ahmad Zain Sarnoto \\ Institut PTIQ Jakarta \\ Email: ahmadzain@ptiq.ac.id

\begin{abstract}
Abstrak
Kemampuan berkomunikasi dalam keluarga sangat diperlukan, karena hambatan berkomunikasi dalam keluarga akan berpengaruh kepada harmonisasi hubungan suami, istri dan anak-anaknya. Alquran sebagai kitab suci umat Islam tidak saja berisi tentang aturan tata cara dalam ibadah saja, namun mengandung unsur adanya isyarat Pendidikan komunikasi dalam keluarga. Tujuan penelitian ini akan mengkaji tentang Metode Komunikasi yang ideal dalam Pendidikan keluarga menurut Al-Quran. Metode yang digunakan dalam penelitian ini adalah metode kualitatif dengan pendekatan analisis, sumber data di dapatkan dari bahan literatur berupa buku, jurnal dan Pustaka lainnya. Temuan penelitian ini menunjukan bahwa ada beberapa isyarat bentuk komunikasi yang digambarkan dalam Al-Quran yang berhubungan dengan metode komunikasi, yaitu metode Qaulan baliigha, Qaulan maisuura, qaulan layyina, qaulan ma"rufa, qaulan kariima dan qaulan sadiida, term komunikasi tersebut memberikan isyarat tentang cara berkomunikasi yang baik, dalam konteks pendidikan keluarga komunikasi yang efektif adalah bagian dari penanaman Pendidikan moral dan agama, bahkan dapat mempengatuhi sikap sosial berupa kejujuran, kedisiplinan, sikap santun dan perilaku baik lainnya. Kesimpulan dalam penelitian ini adalah bahwa untuk menghindari adanya konflik dalam keluarga diperlukan metode komunikasi yang efektif, dan Alquran telah memberikan isyarat bagaimana membangun komunikasi yang ideal dalam keluarga.
\end{abstract}

Kata Kunci: Metode, Komunikasi, Pendidikan, keluarga, Alquran

\begin{abstract}
[The Ideal Method Of Communication In Family Education According To The Quran]. The ability to communicate in family is very necessary because communication barriers in family will affect the harmonization of the relationship between husband, wife, and children. Al-Qur'an as the holy book of Muslims not only contains the rules of procedure in worship, but also contains elements of communication education in family. The purpose of this study to discuss the ideal method of communication in family education according to the Quran. The method used in this study is a qualitative method with an analytical approach, the data sources are obtained from literature in the books, journals, and other libraries. The findings of this study indicate that there are several forms of communication described in the Qur'an related to the communication method, namely the method of Qaulan baliigha, Qaulan maisuura, qaulan layyina, qaulan ma'rufa, qaulan kariima and qaulan sadiida, these communication terms provide a signal about how to good communication, in the context of family education, effective communication is part of the cultivation of moral and religious education, it can even influence social attitudes in the form of honesty, discipline, politeness and other good behaviour. The conclusion in this study is to avoid conflict in the family, an effective communication method is needed, and the Qur'an has given a signal how to build ideal communication in the family
\end{abstract}

Keywords: Method, Communication, Education, Family, Al-Qur'an

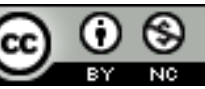

This work is licensed under a Creative Commons Attribution-NonCommercial 4.0 International License 


\section{PENDAHULUAN}

K ehidupan rumah tangga tidak lepas dari berbagai persoalan, dalam konteks ilmu komunikasi sumber konflik dimungkinkan karena adanya salah informasi atau salah persepsi dan hal ini dapat berimplikasi pada keharmonisan rumah tangga (Rimporok, 2015). Bahkan tidak jarang dalam keluarga pemicu munculnya berbagai persoalan dilatarbelakangi salah satunya masalah komunikasi, terlebih bagi keluarga yang suami dan istri sibuk bekerja sehingga komunikasi dengan anak dan anggota tidak terbangun dengan baik. Komunikasi yang berlangsung dalam keluarga secara timbal balik dari orang tua ke anak dan sebaliknya (Sobandi \& Dewi, 2017).

Komunikasi dapat dimaknai sebagai bentuk interaksi individu sebagai makhluk sosial dan menciptakan kebersamaan, saling bertukar pendapat atau gagasan dengan orang lain (Rahmawati \& Gazali, 2018). Komunikasi yang harmonis dalam keluarga adalah bagian dari proses Pendidikan, penanaman nilai-nilai ajaran agama dan akhlak dalam tinjauan pegagogis akan membentuk karakter (Mizani, 2017), maka interaksi komunikasi dalam keluarga antara orang tua akan membentuk karakter anak (Suryadi, 2010) Dengan demikian komunikasi yang terjalin dengan harmonis dalam keluarga dapat membantu menumbuhkan sikap dan perilaku yang baik pada anak.

Tujuan komunikasi dalam Islam tidak sekadar sampainya pesan dan terjadinya perubahan sikap serta perilaku yang saling berinteraksi, tetapi terwujudnya kemaslahatan dalam berinteraksi berkomunikasi (Ghani, 2001). Nilai-nilai Ilahiyah menjadi landasan utama dalam komunikasi Islam (Alquran dan Alhadis) (Muslimah, 2016). Melalui penanaman nilai-nilai llahiyah dalam kecerdasan komunikasi verbal dalam Alquran diharapkan akan menekan bahkan menghilangkan berbagai macam konflik. Dalam kehidupan rumah tangga kesibukan orang tua dengan aktifitasnya kadang berpengaruh terhadap intensitas komunikasi dan dapat memunculkan konflik (Zainab, 2017). Bahkan Tidak sedikit organisasi yang mengalami kegagalan terkait kurang efektifnya komunikasi (Fahreza et al., 2018). Maka orang tua perlu mengetahui bahwa interaksi komunikasi yang intens berupa percakapan atau dialog akan menumbuhkan sikap saling menghargai. Sebaliknya jika komunikasi yang dibangun orang tua terhadap anak dengan sikap acuh tak acuh, memaksakan kehendak orang tua akan berpengaruh pada perilaku anak yang tidak baik (Silaban et al., 2015).

Interaksi dalam Komunikasi mengacu adanya tindakan, oleh seseorang kepada orang lain, dalam proses pengiriman pesan dari pengirim (komunikator) kepada penerima pesan (komunikan) terkadang mengalami gangguan (noise), dalam konteks tertentu gangguan tersebut berpengaruh pada kualitas komunikasi yag berlangsung dan membutuhkan umpan balik (Sarnoto, 2002). Pendapat tersebut memberikan indikasi bahwa proses komunikasi adalah adanya tindakan atau hal yang sengaja oleh seseorang kepada orang lain dan memiliki pengaruh. Dengan demikian, komunikasi yang terjalin antar individu dapat mengubah sikap seseorang (Sarnoto \& Mahpudin, 2019). Tidak berlebihan jika dikatakan bahwa interaksi yang terjadi dalam keluarga adalah bagian dari penanaman Pendidikan moral dan agama, bahkan intensifnya komunikasi orang tua kepada anaknya dapat mempengatuhi sikap sosial berupa kejujuran, kedisiplinan, sikap santun dan perilaku baik lainnya (Sakti \& Sulung, 2020).

Dalam konteks pendidikan sebagai sebuah proses pembelajaran, maka pendidikan komunikasi dalam lingkungan keluarga, adalah terjalinnya komunikasi antara kedua orang tua dan anak serta anggota keluarga lain yang dapat menimbulkan respon pada perubahan tingkah laku anak, dalam proses komunikasi keseharian anak akan cenderung mengikuti perkataan kedua orang tua dan anggota keluarga yang lain (Sarnoto, 2016).

Idealnya dalam rumah tangga muslim, dalam membangun budaya komunikasinya keluarga dengan bermusyawarah (syura). (Takariawan, 1997) Adanya prinsip syura (musyawarah) ini dimaksudkan untuk mengembangkan mekanisme komunikasi yang tidak terjadi searah saja akan tetapi lebih 
aspiratif. Berdialog memiliki pengaruh meningkatkan kualitas dalam membangun hubungan komunikasi, termasuk dalam keluarga (Juniawati, 2015).

Pola komuniaksi yang efektif dalam keluarga perlu dibangun agar terjalin hubungan yang harmonis dan tercipta saling memiliki serta menghargai antar anggota keluarga (Oadratulloh, 2018). karena Komunikasi dianggap efektif jika interaksi komunikator (orang tua) dan komunikan (anak) berlangsung saling memahami isi pesan yang disampaikan, komunikasi selain informatif juga persuasive sebagi bagian dari kegiatan komunikasi (Haslinda, 2018).

Alquran sebagai kitab suci yang memberikan petunjuk kepada umat dalam mencapai kebagiaan dunia dan akhirat, tidak saja berisi pokok ajaran tentang aqidah dan syariat, namun juga menyinggung aspek kehidupan sebagai makhluk sosial, diantaranya memberikan isyarat tentang cara berkomunikasi yang baik melalui ayat-ayat yang membahas tentang prinsip-prinsip komunikasi ideal.

\section{METODE PENELITIAN}

Metode yang digunakan dalam penelitian ini adalah metode kualitatif noninteraktif karena sumber datanya bukan manusia melainkan dokumen, disebut juga penelitian analisis (Sukmadinata, 2010).

Penelitian ini termasuk jenis penelitian kepustakaan (library research), di mana sumber data diperoleh dari berbagai literatur yang memiliki kaitan dengan pendidikan keluarga melalui proses komunikasi dan isyarat Alquran tentang komunikasi. Sedangkan pengumpulan datanya menggunakan teknik dokumentasi, dimana data diperoleh dari sumber berupa buku, jurnal dan sebagainya (Zed, 2008). Adapun analisis data yang di gunakan adalah analisis isi (content analysis) dimana teknik sistematis yang digunanakan untuk menganalisis term komunikasi dalam Alquran sebagai metode komunikasi yang ideal dalam pendidikan keluarga.

\section{TEMUAN DAN PEMBAHASAN}

\section{Temuan}

Nabi Ibrahim a.s memberikan keteladanan dalam masalah pendidikan komunikasi Islam dalam keluarga. Keteladanan ini dapat diketahui tatkala beliau diperintahkan oleh Allah Swt.. untuk menyembelih putranya Ismail a.s, beliau tidak langsung melaksanakan perintah dari Allah tersebut, akan tetapi terlebih dahulu meminta komentar anaknya tentang pesan mulia itu.

Kasus tersebut terdapat dalam Alquran surat al-Shaffat ayat 102, sebagaimana firman Allah SWT.

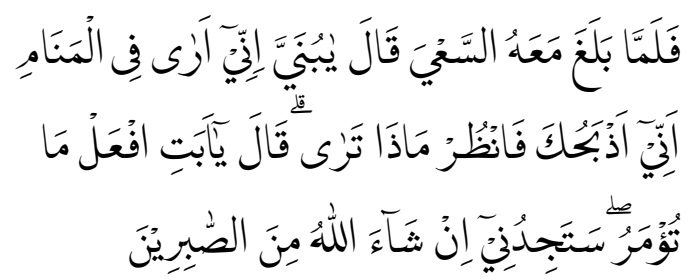

"Ketika anak itu sampai pada (umur) ia sanggup bekerja bersamanya, ia (Ibrahim) berkata, "Wahai anakku, sesungguhnya aku bermimpi bahwa aku menyembelihmu. Pikirkanlah apa pendapatmu?" Dia (Ismail) menjawab, "Wahai ayahku, lakukanlah apa yang diperintahkan (Allah) kepadamu! Insyaallah engkau akan mendapatiku termasuk orang-orang sabar.". (QS. al-Shaffat 37: 102).

Firman Allah dalam ayat di atas telah memberi isyarat pada Nabi Ibrahim untuk menyembelih putra beliau yang bernama Ismail setelah berusia balig dan telah berperilaku seperti orang dewasa serta mengikuti Ibrahim. Nabi Ibrahim bermimpi tiga malam berturutturut yang memerintahkan menyembelih Ismail, dan itu dilakukan beliau dengan sikap demokratis dan meminta pendapatnya (Shihab, 2006). Firman Allah tersebut di atas tercermin pula selain prinsip syura, terdapat pula keharmonisan komunikasi dalam keluarga Ibrahim. Ibrahim memanggil anak-naknya dengan sebutan "ya bunayya” (يُبتَنَ), sebuah ungkapan yang amat santun, lembut, penuh kasih sayang. Ismail pun menjawab dengan panggilan mesra pula dengan ungkapan "ya abati" sebuah ungkapan yang penuh hormat dan kasih sayang. 
Orang tua dituntut memperhatikan ayat di atas dan menjadikannya Langkah berkomunikasi dengan lemah lembut kepada anak-anaknya dan memberi kesempatan untuk mengeluarkan pendapat. Selain bermaksud mendidik, membiasakan, dan mencerdaskan anak-anak, juga agar anak tidak ada yang merasa tertekan serta tidak punya penyaluran pemikiran dan kreativitas. Semua itu dimaksudkan sebagai upaya melanggengkan keharmonisan suasana rumah tangga yang Islami dalam mewujudkan pendidikan komunikasi Islami dalam keluarga.

Menyelesaikan berbagai persoalan yang dihadapi anak dalam kehidupannya dapat ditempuh dengan mewujudkan komunikasi dan musyawarah kepada anak. Anak diajak mengungkapkan permasalahan yang menjadi hambatan dalam kehidupannya dan ia pun dituntut menghormati dan memahami seluruh keputusan yang telah dimusyawarahkan lewat komunikasi tersebut. Dengan demikian pesan pendidikan yang disampaikan orang tua dapat diinterpretasi anak serta memaknainya dengan baik yang pada akhirnya mewujudkannya dalam kehidupan sehari-hari. Kondisi yang tercermin seperti ini, melahirkan metode komunikasi yang ideal dalam keluarga dengan baik dan tingkah laku anak pun dapat diarahkan sesuai dengan tujuan pesan yang diinginkan. Alquran menggambarkan bentuk komunikasi dengan beberapa term diantaranya qaulan sadiida (AlAhzab:70), qaulan baligha (QS. an-Nisa/4:63), qaulan layyina (QS. Taha: 44$)$, qaulan ma'rufa (QS. An-Nisa': 5), Qaulan Kariima (QS. AlIsra':23), dan qaulan maisuura (QS.Al-Isra': 28)

\section{Pembahasan}

a. Metode Qaulan Sadîda (Perkataan yang Tegas dan benar)

Metode qaulan sadida (perkataan yang tegas dan mengandung kebenaran) dapat digunakan dalam proses pendidikan komunikasi keluarga, hal ini mengindikasi bahwa pesan yang disampaikan kepada anak dalam pembinaan pendidikannya dengan berkata yang benar harus sesuai dengan Alquran dan hadis serta realitas sosial. Hal ini menjadi prinsip, setidaknya pesan yang diberikan kepada anak mengandung dua hal yaitu "sesuai dengan kriteria kebenaran dan tidak berbohong".
Term qaulan sadida terdapat dalam surat Al-Ahzab ayat 70:

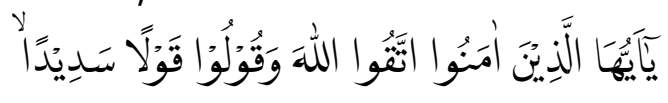

"Wahai orang-orang yang beriman, bertakwalah kamu kepada Allah dan ucapkanlah perkataan yang benar" QS. Al-Ahzab:70. (Agama, 2019)

Ayat di atas menjelaskan bahwa Allah memerintahkan orang yang beriman untuk berkata benar dan tepat sasaran (Agama, 2016). Ungkapan yang benar dan tidak bohong dalam Islam tentu yang disesuaikan dengan tuntutan Alquran dan Alhadis. Alquran sendiri menyindir dengan keras kepada orang-orang yang berbicara tanpa landasan, petunjuk, dan ilmu, sebagaimana firman-Nya dalam surat Luqman ayat 20:

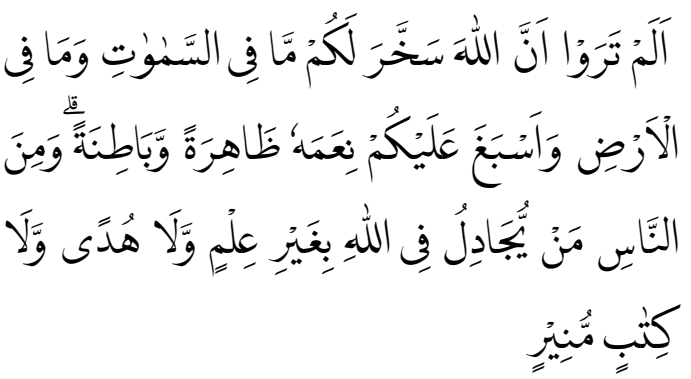

"Tidakkah kamu memperhatikan bahwa sesungguhnya Allah telah menundukkan apa yang ada di langit dan apa yang ada di bumi untukmu. Dia (juga) menyempurnakan nikmatnikmat-Nya yang lahir dan batin untukmu. Akan tetapi, di antara manusia ada yang membantah (keesaan) Allah tanpa (berdasarkan) ilmu, petunjuk, dan kitab suci yang menerangi. (QS. Luqman, 31: 20).

Firman di atas dapat diinterpretasi sebuah komunikasi Islami dengan menggunakan komunikasi verbal dalam menginformasikan tentang Allah sesuai dengan akal dan naql dan hal tersebut merupakan substansi serta metode dalam memberikan pendidikan kepada anak. Metode pendidikan komunikasi Islami yang diungkap dengan perkataan yang tegas itu "sesuai dengan kehendak Allah SWT. dalam tauhid dan sifat-Nya serta tidak bertentangan dengan akal dan naql serta pandangan Rasulullah yang menghendaki kebenaran dan perkataan yang jelas dan itu dilandasi dengan ilmu pengetahuan."

Berbicara yang benar menurut Alquran adalah dalam menyampaikan pesannya selalu 
dilandasi oleh keimanan dan ketakwaan kepada Allah, sehingga penyampaian pesan yang benar berarti sedang melakukan kegiatan amal. Bila ingin sukses dalam berkarir atau ingin memiliki kesuksesan dalam mendidik keluarga ataupun dalam lingkungan masyarakat, maka hal yang paling mendasar adalah berbicara sesuai dengan kebenaran dengan standar Alquran dan sunah. Sebab apa yang diucapkan itulah yang akan didengar dan direkam sehingga menjadi hal yang terbiasa yang dipraktikkan yang pada akhirnya membentuk karakter seseorang terutama dalam lingkungan keluarga. Dalam pepatah Arab dikatakan bahwa al-ummu almadrastu al-ula artinya ibu adalah sekolah/guru pertama bagi anak-anaknya.

Berkata benar dalam lingkungan keluarga berarti mengajarkan kedisiplinan perilaku, hal ini akan memudahkan anak-anak dalam memahami dan mengikuti role model perilaku ayah dan ibunya, namun berbeda dengan ketidakjujuran yang mengandung sikap inkonsistensi sehingga anak-anak merasa sulit bahkan bingung untuk meneladani perilaku ayah dan ibunya. Dengan kata lain mengajarkan ucapan yang benar berarti mengajarkan kemudahan bagi anak sedangkan mengajarkan ucapan bohong berarti mengajarkan kesulitan pada anak khususnya dalam proses berpikirnya.

Alquran menganjurkan kepada manusia untuk selalu berkata yang benar, dan tidak meninggalkan generasi yang lemah. Dengan kata lain berkata benar kepada keluarga berarti mengajarkan anak-anak hidup pantang menyerah dan membentuk keturunan menuju generasi kuat secara fisik dan mental. Kejujuran melahirkan kekuatan sedangkan kebohongan melahirkan generasi lemah.

Metode tersebut sangat penting bagi orang tua dalam mendidik anak-anaknya, karena tidak jarang orang tua kurang konsisten dengan keputusan yang diambil dan dikomunikasikan. Dampaknya anak menjadi kurang mengindahkan kebijaksanaan yang dikeluarkan orang tua dan menghambat komunikasi dalam keluarga. Atas dasar itu mengkomunikasikan pendidikan kepada anak mengharuskan orang tua memperhatikan bahasa yang baik dan sopan, tenang, tidak emosional, tidak menghina, bersikap lemah lembut, tidak meninggikan nada suaranya, dan berusaha menarik hati anak agar berkesan (Darussalam, 1996).

Penggunaan metode ini menuntut sebuah pemahaman tinggi dari orang tua tentang suasana hati anak, tepatnya dapat dilakukan dengan pendekatan psikologis. Memberikan wejangan dan arahan sebagai pesan yang ditransmisikan sangat dimungkinkan diterima oleh anak manakala dilakukan dengan menyentuh suasana hati dan kemudian merefleksikan dalam contoh yang dianggap tidak terlalu menyinggung perasaan. Metode qaulan sadîdan sangat tepat dipergunakan dalam mengkomunikasikan pendidikan sosial, agama dan psikologis.

b. Metode Qaulan Balîgha (Perkataan yang membekas pada jiwa)

Dalam Bahasa Arab, Kata 'baligh' bermakna sampai, mengenai sasaran atau mencapai tujuan. Jika kata ini dikaitkan dengan qaul (ucapan), maka baligh bermakna fasih, bisa juga bermakna jelas, terang, tepat mengungkap apa yang dikehendakinya. Sesuai dengan arti tersebut, maka kata qaulan baligha berarti ucapan yang efektif (Rakhmat, 2000). Hal tersebut terdapat dalam Alquran, Allah Swt.. berfirman:

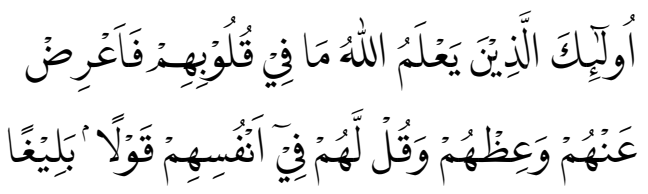

"Mereka itulah orang-orang yang Allah ketahui apa yang ada di dalam hatinya. Oleh karena itu, berpalinglah dari mereka, nasihatilah mereka, dan katakanlah kepada mereka perkataan yang membekas pada jiwanya. (QS. an-Nisa/4:63).

Dalam tafsir ringkas kementerian agama menjelaskan bahwa ayat di atas Allah Swt. memberikan bantahan atas pengakuan orangorang munafik, kemudian memberikan kepada umat Islam petunjuk tentang cara menghadapi kebohongan orang-orang munafik tersebut. Allah Swt. mengetahui isi hati orang-orang munafik. Maka, kaum muslimin diperintahkan untuk berpaling dari mereka, yakni tidak menghiraukan dan tidak percaya pada ucapan serta sumpah mereka, dan diperintahkan kaum muslimin untuk memberikan kepada kaum munafik nasihat yang dapat menyentuk hati 
mereka, serta nasihat yang membekas dan mampu menghujam pada jiwa mereka orangorang munafik (Agama, 2016).

Dalam konteks Pendidikan ayat di atas memberikan pedoman bagaimana penggunaan metode qaulan baligha dalam memberikan pelajaran atau nasehat hendaknya dengan kalimat mampu diterima dan membekas pada orang menerima nasehat atau pelajaran.

Menerapkan prinsip qaulan balîgha dalam lingkungan keluarga adalah dengan menyesuaikan kepada sifat-sifat komunikan yang diajak berbicara, penyesuaian tersebut dapat menggunakan kerangka tujuan, pengalaman dari audien serta mampu menyentuh sekaligus hati dan akalnya (Rakhmat, 2000). Prinsip ini dikuatkan oleh firman Allah sebagaimana berikut:

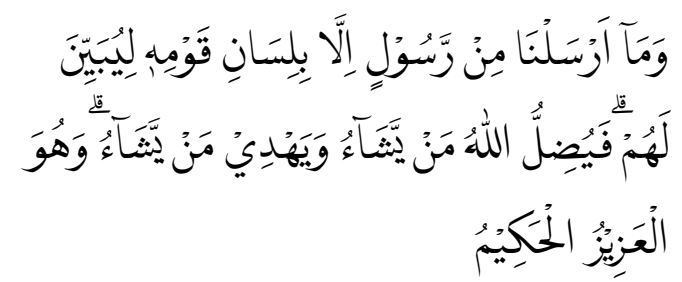

"Kami tidak mengutus seorang rasul pun, kecuali dengan bahasa kaumnya, agar dia dapat memberi penjelasan kepada mereka. Maka, Allah menyesatkan siapa yang Dia kehendaki (karena kecenderungannya untuk sesat), dan memberi petunjuk kepada siapa yang Dia kehendaki (berdasarkan kesiapannya untuk menerima petunjuk). Dia Yang Mahaperkasa lagi Mahabijaksana." (Surat Ibrahim/14:4)

Prinsip qaulan balîghan dapat tercapai apabila komunikator mampu menyampaikan ucapan yang menggugah hati dengan menyentuh perasaannya dan membangunkan pikiran dengan menyampaikan ucapan yang menyentuh akalnya sekaligus. Aristoteles menyebut tiga cara persuasive dalam mempengaruhi manusia yaitu ethos, logos dan pathos. Tiga cara tersebut dapat merangsang anak dalam proses Pendidikan untuk mengetahui materi dalam rangka meningkatkan silaturrahmi dan solidaritas antar individu.

Orang tua perlu menerapkan qaulan balîgha dalam mendidik anak di lingkungan keluarganya. Karena ungkapan yang tepat dan tuntas anak memiliki pemahaman makna yang tuntas sehingga tidak mampu di pengaruhi dengan pemikiran atau pun makna yang salah. Sehingga dengan demikian anak dapat berperilaku secara beradab. Anak yang beradab adalah anak yang mampu menyampaikan pesan secara tepat dan berbuat pada waktu yang tepat.

Husien Mazhahiri mengungkapkan pembicaraan yang tepat sasaran sangat berkaitan dengan agama dan hukumhukumnya, bahkan kadang-kadang berkaitan dengan tradisi yang berlaku serta berkaitan dengan prinsip-prinsip pergaulan sehari-hari (Mazhahiri, 1999). ungkapan ini mengilustrasikan bagi orang tua membiasakan penggunaan Bahasa yang dikenal dan berlaku di tengah masyarakat, tidak berbicara dengan dialek yang ganjil dan aneh dalam memberikan pendidikan kepada anak. Anak diajari cara berbicara yang baik disertai sopan santun dan juga cara bergaul dengan sesamanya baik dengan yang tua maupun dengan yang muda maupun yang sebaya dengannya. Prinsip ini tepatnya dapat digunakan dalam memberikan materi Pendidikan akhlak, agama dan sosial.

\section{c. Metode Qaulan Layyina}

Pengertian layyina secara bahasa adanya lemah lembut, sehingga qaulan layyina artinya perkataan yang lemah lembut (Rusmalita, 2015). Dalam Alquran terdapat kisah Nabi Musa dan Nabi Harun yang diperintahkan oleh Allah untuk berdakwah kepada Fir'aun dengan qaulan layyina dengan harapan ia menjadi sadar, sebagaimana firman Allah.

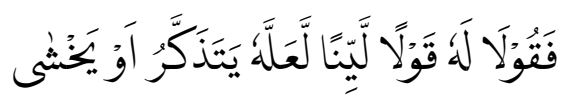

“Berbicaralah kamu berdua kepadanya (Fir'aun) dengan perkataan yang lemah lembut, mudahmudahan dia sadar atau takut." (QS. Taha: 44), (Agama, 2019)

Dalam tafsir ringkas kementerian agama $\mathrm{Rl}$, ayat tersebut berkisah tentang perintah Allah Swt. kepada Nabi Musa dan Harun untuk pergi kepada Fir'aun yang sombong dan durhaka serta telah melampaui batas. Dengan bekal mukjizat yang dimiliki mereka berdua segera menghadap Fir'aun dan memberinya nasihat dengan ucapan yang lemag lembut. $\mathrm{Di}$ ajaknya Fir'aun untuk beriman kepada Allah dan diseru dengan cara yang baik (Agama, 2016). 
Term qaulan layyina dimaknai sebagai perkataan atau ujaran yang menyentuh hati karena lemah lembut, dan menunjukan akhlak yang baik (Murtiningsih, 2018).

Dalam konteks pendidkan keluarga, metode komunikasi qaulan layyina dapat dijadikan panduan orang tua dalam membangun interaksi dengan anak-anaknya. Sehingga pesan pendidikan yang disampaikan orang tua sebagai komunikator dapat dimengerti dan dipahami oleh anak sebagai komunikan.

\section{d. Metode Qaulan Ma'rufa}

Pengertian qaulan ma'rufa terdiri dari dua kata, qaulan dan ma'rufa, qaulan diartikan dengan perkataan (Hamdi et al., 2021), sedang kata ma'rufa, berasal dari kata 'urf' yang diartikan dengan adat atau kebiasaan yang dilakukan oleh masyarakat. Dalam Alquran Term qaulan ma'rufa banyak digunakan oleh orang yang beriman dalam menjalin hubungan kekeluargaan dan bermasyarakat. Di antara ayat yang menjadi term qaulan ma'rufa dalam surat An-Nisa' ayat 5:

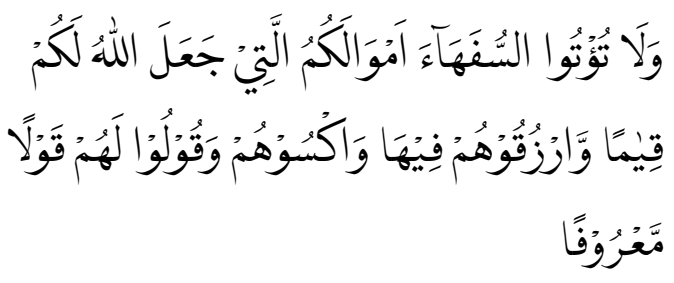

"Janganlah kamu serahkan kepada orang-orang yang belum sempurna akalnya harta (mereka yang ada dalam kekuasaan)-mu yang Allah jadikan sebagai pokok kehidupanmu. Berilah mereka belanja dan pakaian dari (hasil harta) itu dan ucapkanlah kepada mereka perkataan yan baik" QS. An-Nisa': 5).

Dalam tafsir ringkas kemenag, dijelaskan bahwa ayat tersebut berkaitan dengan perintah kepada pengasuh anak yatim memenuhi hakhak mereka dan larangan menyerahkan harta kepada mereka karena belum cukup umur dan mampu mengurus, hal ini dikuatirkan harta yang mereka miliki dan dititipkan kepada pengasuh atau keluarga dekat yang mengurusnya, jika berikan kepada meraka akan habis karena ketidakmampuannya mengelola harta. Allah Swt. memerintahkan kepada pengasuh anak yatim untuk bersikap lemah lembut dalam berinteraksi dan menggunakan perkataan yang baik sehingga mereka merasa nyaman dan tenteram (Agama, 2016).

Dalam konteks Pendidikan keluarga, qaulan ma'rufa memiliki makna kalimat yang halus, ucapan yang tidak membuat orang lain tersinggung, ujaran yang halus lebih cenderung disukai oleh wanita dan anak-anak.

Qaulan ma'rufa sejatinya memiliki makna yang luas, sederhanya ucapakan ini adalah menyenangkan hati, mudah dipahami dan tidak memicu kemarahan atau kesedihan orang yang diajak berbicara. Qaulan ma'rufa juga bermakna pembicaraan yang mengandung manfaat dan memberikan tambahan pengetahuan serta dapat mencerahkan pikiran (Aziz, 2019).

Sejatinya qaulan ma'rufa dalam konteks komunikasi dalam keluarga adalah etika dan pedoman bertutur kata kepada orang lain, dalam hal ini orang tua sebagai komunikator dapat memberikan contoh pengajaran kepada anak-anak dan anggota keluarga lainnya dalam interaksi menggunakan Bahasa yang halus dan mudah dimengerti sehingga nasihat sebagai pesan dapat di terima oleh anak-anak sebagai audien.

\section{e. Metode Qaulan Karima}

Secara Bahasa makna karima artinya mulia, sehingga qaulan kariima dapat dipahami sebagai perkataan yang mulia yang mengandung lemah lembut dan merendahkan diri, maka qaulan karima khususnya diperintahkan saat berdialog denga orang tua. Alquran memberikan isyarat tentang etika berkomunikasi dalam keluarga antara anak dengan orang tua, isyarat tersebut dapat dijadikan pedoman berkomunikasi dalam keluarga, sebagaiana firman Allah.

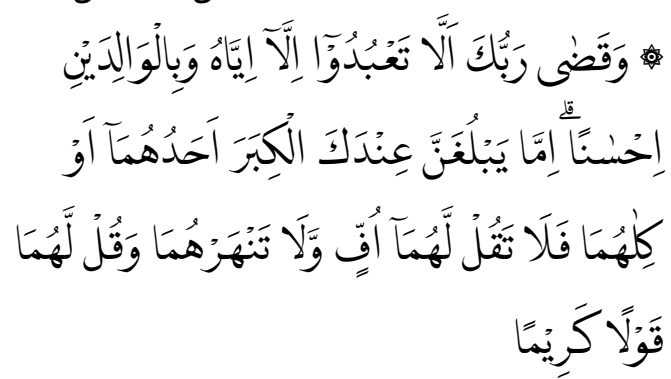

"Tuhanmu telah memerintahkan agar kamu jangan menyembah selain Dia dan hendaklah berbuat baik kepada ibu bapak. Jika salah seorang di antara keduanya atau kedua-duanya sampai berusia lanjut dalam pemeliharaanmu, 
maka sekali-kali janganlah engkau mengatakan kepada keduanya perkataan "ah" dan janganlah engkau membentak keduanya, dan ucapkanlah kepada keduanya perkataan yang baik." QS. Al-Isra': 23. (Agama, 2019)

Ayat di atas memberikan penjelasan tentang dua golongan manusia, yaitu ada yang menghendaki kehdiupan dunia saja dan ada yang menghendaki kehidupan dunia dan akhirat. Pada ayat tersebut juga memberikan pedoman etika pergaulan sesama manusia. Sebagaimana ayat tersebut. "Dan Tuhanmu telah menetapkan dan memerintahkan agar kamu wahai sekalian manusia jangan menyembah selain Dia dan hendaklah berbuat baik kepada ibu bapakmu dengan sebaikbaiknya. Jika salah seorang di antara keduanya atau kedua-duanya sampai berusia lanjut dan mereka berada dalam pemeliharaanmu, maka sekali-kali janganlah kamu menyakiti keduanya, misalnya dengan mengatakan kepada keduanya perkataan "ah", yakni perkataan yang mengandung makna kemarahan atau kejemuan, dan janganlah engkau membentak keduanya jika mereka merepotkan kamu atau berbuat sesuatu yang kamu tidak menyukainya, dan ucapkanlah kepada keduanya perkataan yang mulia, yakni perkataan yang baik, yang mengandung penghormatan dan kasih sayang."(Agama, 2016)

Dalam konteks Pendidikan keluarga, qaulan kariima adalah perkataan yang mengandung kebajikan, mudah dipahami dan lembut tidak menyakitkan serta tidak menggurui penerima pesan, dalam hal ini orang tua yang memberikan pengajaran dan nasihat kepada anak-anaknya dengan pendekatan Bahasa yang lemah lembut dan mudah dimengerti anaknya karena mengandung hikmah

\section{f. Qaulan Maisura}

Secara Bahasa kata ma'rufa adalah isim maf'ul dari 'rafa - ya'rifu -'urfan - ma'rufan yang maknanya mengerjakan kebaikan.(Ridho \& Hariyadi, 2021) sedangkan kata Qaulan maisura maknanya adalah perkataan yang mudah dimengerti oleh penerima pesan (komunikan).(Rusmalita, 2015)
Dalam konteks komunikasi aspek Bahasa yang digunakan sangat berpengaruh maka dianjurkan menggunakan Bahasa yang mudah dipahami sehingga mudah dicerna. Dalam Alquran terdapat term qaulan maisura yang maknai sebagai perkataan yang mudah dipahami dan sebagai tuntunan dalam berkomunikasi sebagaimana firman Allah dalam surat Al-Isra' ayat 28.

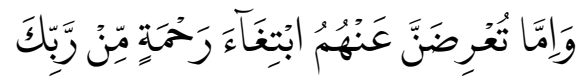

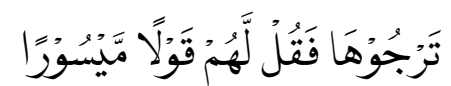

"Jika (tidak mampu membantu sehingga) engkau (terpaksa) berpaling dari mereka untuk memperoleh rahmat dari Tuhanmu yang engkau harapkan, ucapkanlah kepada mereka perkataan yang lemah lembut." QS. Al-Isra': 28. (Agama, 2019)

Ayat di atas menjadi tuntunan kepada orang yang karena suatu hal tidak memberikan bantuan kepada orang yang memerlukan, terlebih jika yang memerlukan bantuan adalah keluarga dekat atau orang miskin. Berpaling dari mereka yang memerlukan bantuan bukan karena enggan tetapi karena tidak adanya materi, dan mereka memohon kepada Allah untuk mendapatkan rahmat. Dalam hal ini, penolakan yang diberikan dengan Bahasa yang tidak menyakitkan karena ucapakannya kasar (Agama, 2016).

Dalam konteks Pendidikan keluarga makna qaulan maisura adalah tuntunan bagaimana seharusnya orang tua berbicara kepada anaknya yaitu dengan lemah lembut, memperlakukan anaknya dengan arif dan bijak, sehingga tertanam dalam jiwa anak dan anggota keluarga ujaran yang baik. Karena ucapan yang keluar dari orang tua mudah dipahami dan dicerna, anak akan tertarik dan bersimpati kepada orang tua.

\section{PENUTUP}

\section{Simpulan}

Munculnya persoalan dalam rumah tangga salah satu bersumbernya dari komunikasi yang tidak lancar antara orang tua dengan anak dan sebaliknya, atau antara anak dengan anggota keluarga yang lain. Atas dasar adanya komunikasi yang tak lancar dalam keluarga itu 
anak-anak merasa terkekang hidupnya dalam rumah tangga, pendapat mereka tidak didengar apalagi dihargai, akhirnya mereka melampiaskan seluruh keinginan dan harapannya di luar rumah. Orang tua perlu menyadari bahwa anak-anak juga perlu dibiasakan memberikan pendapat dan mengungkapkan pemikirannya kepada kedua orang tua dan masalah-masalah yang dihadapi mereka.

Untuk menghindari adanya persoalan komunikasi dalam keluarga, diperlukan metode atau cara mewujudkan pendidikan komunikasi Islami, dan Alquran telah memberikan isyarat tentang hal tersebut diantaranya dengan metode Qaulan Sadîda (Perkataan yang Tegas), Metode Qaulan Balîgha, Qaualan Layyina, Qaulan Karimma, Qaulan Baligha, Qaulan Ma'rufa. Dari metode komunikasi yang ada dalam Alquran dapat menjadi pegangan orang tua dalam melakukan pendidikan keluarga, sehingga menghindari adanya potensi konflik.

\section{Rekomendasi}

Hasil kajian ini diharapkan dapat dijadikan pertimbangan para orang tua dalam proses Pendidikan komunikasi dalam keluarga. Selain itu, bagi pemangku kebijakan (Dirjen Bimas Islam Kemanag RI, direktorat Bina KUA dan Keluarga Sakinah) dapat dijadikan bahan tambahan dalam Menyusun panduan yang lebih komprehensif terkait pembinaan keluarga sakinah. 


\section{DAFTAR PUSTAKA}

Agama, K. (2016). Tafsir Ringkas Kemenag (M. M. Hanafi (ed.)). Jakarta: Kementerian Agama RI dan Pusat Studi Alquran (PSQ).

Agama, K. (2019). Terjemah Alquran Kemenag. Jakarta: Kementerian Agama RI.

Aziz, M. A. (2019). Public Speaking: Gaya Dan Teknik Pidato Dakwah. Jakarta:Prenadamedia Group.

Darussalam, G. (1996). Dinamika Ilmu Dakwah Islamiah. Malaysia: Utusan Publication \& Distribution Sdn Bhd.

Fahreza, A., Sugandi, \& Wibowo, S. E. (2018). Analisa Penerapan Komunikasi Efektif Untuk Pelayanan Publik di Dinas Kependudukan dan Catatan Sipil Kota Samarinda. EJournal LImu Komunikasi, 6(3), 149-158.

Ghani, Z. A. (2001). Islam Komunikasi dan Teknologi Maklumat. Kuala Lumpur: Dasar Cetak Sdn Bhd.

Hamdi, S., Hamidah, H., Ilmiani, A. M., \& Musthofa, K. (2021). Menggaungkan Pendidikan Qaw lan Ma ' rufa sebagai Etika Pergaulan dalam Menyikapi Body Shaming. Jurnal Pendidikan Agama Islam Al-Thariqah Vol., 6(1), 36-55. https://doi.org/10.25299/al-thariqah.2021.vol6(1).6823

Haslinda. (2018). Perspektif Makna Komunikasi Islam. AL-HIKMAH: Media Dakwah, Komunikasi, Sosial Dan Budaya, 9(2), 95-110. https://doi.org/10.32505/hikmah.v9i2.1743

Juniawati. (2015). Komunikasi dalam Keluarga: Upaya Strategis Mencegah Kekerasan pada Anak. Raheema: Jurnal Studi Gender Dan Anak -, 2(1), 39-49. https://doi.org/10.24260/raheema.v2i1.167

Mazhahiri, H. (1999). Pintar Mendidik Anak: Panduan Lengkap Bagi Orang Tua, Guru dan Masyarakat Berdassarkan Ajaran Islam. Jakarta: lentera.

Mizani, Z. M. (2017). Komunikasi Orang Tua dan Anak dalam Islam (Tinjauan Pedagogis Komunikasi Nabi Ibrahim dengan Nabi Isma'il dalam Alquran). Ibriez : Jurnal Kependidikan Dasar Islam Berbasis Sains, 2(1), 95-106. https://doi.org/10.21154/ibriez.v2i1.28

Murtiningsih. (2018). Teologi Perkataan: Perkataan-perkataan Yang Dicintai dan Dibenci Oleh Allah Menurut Pandangan Hamka. Jurnal Raden Fatah (JSA), 2(2), 98-119. http://dx.doi.org/10.1016/j.cirp.2016.06.001\%0Ahttp://dx.doi.org/10.1016/j.powtec.2016.12.055\% OAhttps://doi.org/10.1016/j.ijfatigue.2019.02.006\%0Ahttps://doi.org/10.1016/j.matlet.2019.04.024 \%0Ahttps://doi.org/10.1016/j.matlet.2019.127252\%0Ahttp://dx.doi.o

Muslimah. (2016). Etika komunikasi dalam persfektif islam. Journal Etika Komunikasi Dalam Persfektif Islam, $13(2), 1-11$.

Qadratulloh, W. (2018). Tuntunan Al Quran Mengenai Pembinaan Toleransi Melalui Komunikasi Pada Anak Di Keluarga. Jurnal Keluarga Sehat Sejahtera, 16(31), 96-106. https://doi.org/10.24114/jkss.v16i31.10177

Rahmawati, \& Gazali, M. (2018). Pola Komunikasi Dalam Keluarga. Al-Munzir, 5(1), 488-497.

Rakhmat, J. (2000). Psikologi Komunikasi. Bandung: Remaja Rosdakarya.

Ridho, A. R., \& Hariyadi, M. (2021). REFORMULASI ETIKA DAKWAH BERBASIS KOMUNIKASI PROFETIK DALAM ALQURAN. Komunike Jurnal Komunikasi Penyiaran Islam, XIII(1), 53-78.

Rimporok, P. B. (2015). INTENSITAS KOMUNIKASI DALAM KELUARGA UNTUK MEMINIMALISIR KENAKALAN REMAJA DI DESA MAUMBI KECAMATAN KALAWAT KABUPATEN MINAHASA UTARA OLEH. Journal Acta Diurna, IV(1).

Rusmalita, S. (2015). Komunikasi Efektif Membangun Kearifan Dalam Dakwah. Al-Hikmah, 8(1), 41-49. https://doi.org/10.24260/al-hikmah.v8i1.70

Sakti, G., \& Sulung, N. (2020). Komunikasi Dalam Keluarga Terhadap Perilaku Menyimpang Anak Dan Remaja ( Systematic Review). Human Care Journal, 5(2), 522. https://doi.org/10.32883/hcj.v5i2.791

Sarnoto, A. Z. (2002). Pengantar IImu Komunikasi (1st ed.). Bekasi: Pustaka Faza Amanah.

Sarnoto, A. Z. (2016). Keluarga Dan Peranannya Dalam Pendidikan Karakter Pada Anak Usia Dini. Profesi: Jurnal IImu Pendidikan Dan Keguruan, 5(1), 48-58.

Sarnoto, A. Z., \& Mahpudin, A. (2019). Pengaruh Gaya Komunikasi Dan Keteladanan Guru Terhadap Disiplin Siswa Dalam Pendidikan Islam Studi Kasus Di Sekolah Dasar Islam (SD) Budi Mulia Dua Bintaro Ciputat, Tangerang Selatan. Profesi: Jurnal IImu Pendidikan Dan Keguruan, 7(2), 55-64.

Shihab, M. Q. (2006). Tafsir Al Misbah, Pesan, Kesan dan Keserasian Al Quran (V). Jakarta: Lentera Hati.

Silaban, D. I., Mingkid, E., \& Kalesaran, E. R. (2015). KOMUNIKASI ANTARPRIBADI ORANG TUA DALAM PEMBENTUKAN KONSEP DIRI REMAJA PADA KELUARGA DI LINGKUNGAN III KELURAHAN BAHU. Jurnal Acta Diurna, IV(3).

Sobandi, 0., \& Dewi, N. (2017). Urgensi Komunikasi Dan Interaksi Dalam Keluarga. Atthulab: Islamic Religion Teaching and Learning Journal, 2(1). https://doi.org/10.15575/ath.v2i1.2722

Sukmadinata, N. S. (2010). Metode Penelitian Pendidikan. Bandung: remaja Rosyda Karya.

Suryadi, E. (2010). Model Komunikasi Efektif bagi Perkembangan Kemampuan Berpikir Kreatif Anak. Jurnal IImu Komunikasi, 8(4), 3. http://jurnal.upnyk.ac.id/index.php/komunikasi/article/view/135 
Takariawan, C. (1997). Pernik-Pernik Rumah Tangga Islami Tatanan dan Perannya dalam Masyarakat. Solo: Intermedia.

Zainab, S. (2017). KOMUNIKASI ORANG TUA-ANAK DALAM AL-QURAN (Studi terhadap QS. Ash-Shaffat ayat 100102). Nalar, 1(1), 48-58.

Zed, M. (2008). Metodologi Penelitian Kepustakaan. Jakarta: Yayasan Obor Indonesia. 